DOI: $10.33741 / 0435-1991.41 .24$

\title{
ОСНОВНІ ПРИНЦИПИ ПРОТИБОЛЬОВОЇ ТЕРАПЇ̈ ПРИ ОНКОГЕМАТОЛОГІЧНІЙ ПАТОЛОГІї
}

\author{
Старіков А. В., Семеняка В. І., Авер'янов С. В. \\ ДУ «Інститут гематологї̈ та трансфузіології НАМН України», \\ Киів, Україна
}

\section{Резюме}

У статті представлено аналіз клінічної ефективності та безпечності препаратів при лікуванні онкогематологічних хворих з больовим синдромом. Авторами проаналізовані основні групи препаратів та їхня ефективність при лікуванні хворих за стандартизованими протоколами при наявності різних ускладнень. Проаналізовано схеми застосування різних анальгетиків та надано шкалу їхньоі активності. Показано доцільність застосування комбінованих аналгетичних nрепаратів.

Ключові слова: онкогематологічна патологія, больовий синдром, аналгетичні препарати, фармакологічні властивості.

Конфлікт інтересів: автори заявляють про відсутність конфлікту інтересів.

Фінансування: дослідження не мало спонсорської підтримки.

\section{BASIC PRINCIPLES OF PAIN THERAPY IN ONCOGEMATOLOGICAL PATHOLOGY}

\author{
Starikov A. V., Semeniaka V. I., Averianov Y. V. \\ SI «Institute of Haematology and Transfusiology of NAMS of Ukraine», \\ Kyiv, Ukraine
}

\begin{abstract}
The article analyzes the main approaches to the treatment of patients with pain due to hematological pathology. Pain therapy depends on the identified causes of pain syndrome often manifested in patients receiving cytotoxic drugs. The pain in cancer patients can be caused by bone marrow aspiration, trepanobiopsy, lumbar puncture. In patients after bone marrow transplantation and immunosuppressive therapy, pain in the oral cavity and mucositis occurred in $75 \%$ of cases. The complications of intensive cytostatic therapy in oncohematological patients may be the pain of herpetic origin. In multiple myeloma, bone pain is the main clinical manifestation of this disease. In this
\end{abstract}


patients it is recommended to prescribe bisphosphonates (paramidronate, zolendronate) for bone pain caused by osteolytic changes. In addition, zoledronic acid in combination with radioactive components such as samarium 153 ethylene diamines today is a promising method of pain relief in patients with refractory bone pain.

For the effective treatment of pain, it is important to make an adequate choice of drugs, taking into account their dose and the characteristics of pharmacokinetics. In addition, it is necessary to take into account the power of the analgesic effect and differentiate the use of drugs depending on the strength of the pain.

Non-steroidal anti-inflammatory drugs should be prescribed with caution at the impaired renal circulation, at risk of bleeding. Opioids occupy the main place in the pain relief of oncohematological patients. The combined use of opiates and nonsteroidal anti-inflammatory drugs, which act synergistically, is more effective than prescribing drugs in each group separately. Of greatest interest are combinations of opiates and non-steroidal anti-inflammatory drugs or non-steroidal anti-inflammatory drugs and local anesthetics. The proposed approaches to pain therapy can be used in medical institutions.

Keywords: oncogematological pathology, pain syndrome, analgesic drugs, pharmacological properties.

Міжнародна асоціація з вивчення болю (The International association for the study of pain (IASP ) визначає біль як «неприємне сенсорне та емоційне відчуття, що пов’язане з дійсним чи потенційним пошкодженням тканин». У липні 2020 року це визначення було розширене і наразі включає не лише фізичний, а й психологічний і соціальний аспекти болю $[1,2]$.

Метою нашої роботи було окреслити коло тих препаратів, які можуть мати перспективу щодо застосування в онкогематології, а не надати рекомендації лікарям для призначення конкретних лікарських засобів та їх точних доз.

Проведення інтенсивної терапії при лікуванні хворих з больовим синдромом залежить від виявлених механізмів його виникнення. Це може бути ноцицептивний біль [3] у результаті пошкодження тканин, нейропатичний біль [4], а в деяких випадках біль є наслідком недостатньої ефективності антиноцицептивних механізмів.

Ноцицептивний (соматичний та вісцеральний) - біль, опосередкований активацією периферичних сенсорних нейронів 3 аксоном та дендритом, які активуються патологічними стимулами. Нейропатичний біль - спричинений травмами периферичної або центральної нервової системи. Основним завданням, для вирішення якого необхідно провести диференціацію нейропатичного та ноцицептивного болю, $є$ визначення оптимального методу знеболення - підбір дози препаратів, їх комбінація, вибір методу анальгезї. 
Оцінка больового синдрому у хворих 3 онкогематологічними захворюваннями проводиться зважаючи на ті фактори, що можуть модулювати інтенсивність болю. Біль завжди супроводжується емоційними переживаннями, що надає йому індивідуальний характер, на що впливають емоційно-особистісні особливості суб'єкта, рівень невротизації, наявність депресивно-іпохондриальних та сенсопатичних проявів. Характер ушкодження тканин, локалізація цих ушкоджень та особливості попереднього лікування $\epsilon$ провідними чинниками при призначення знеболюючої терапії. В практиці часто зустрічаються випадки, коли у одних пацієнтів біль $\epsilon$ наслідком ушкодження тканин, а в інших - гіпералгезії. У першому випадку доцільним може бути збільшення дози знеболюючих засобів, або заміна препаратів на більш сильнодіючі, а в другому - зменшення дози знеболюючих засобів та призначення ад'ювантних препаратів, наприклад транквілізаторів.

Знеболюючі препарати підрозділяють на засоби центральної дії (опіоїдні анальгетики), нестероїдні препарати з аналгетичною активністю, препарати змішаної дії, лікарські засоби периферичної дії (місцеві анестетики) та інші засоби для знеболення (блокатори серотонінових рецепторів, адреноблокатори, міорелаксанти тощо) [5].

Багато 3 етіопатогенетичних процесів, що спричиняють больовий синдром у онкогематологічних хворих, відомі. До них відносяться остеоліз, розширення капсули селезінки та печінки внаслідок інфільтрації органу неотканиною та збільшення їх розміру, головний біль через втрату ліквору (постдуральна пункція); внутрішньочерепна гіпертензія при ураженні пухлиною менінгіальних оболонок або мозку, мукозити, грибкові ураження шкіри та слизових, стискання органів черевної порожнини внаслідок гепатоспленомегалії та збільшення лімфатичних вузлів брижі кишківника, очеревини та заочеревинного простору, застосування агресивних токсичних лікарських засобів, постгерпетична невралгія, невропатії, обумовлені парабілками, амілоїдос, плексопатія шляхом інвазії пухлини та/або стиснення збільшення вузла (лімфоми), менінгізм, стиснення периферичних нервів пухлиною.

Крім того, больовий синдром може розвиватися при виникненні гематом та крововиливів у разі порушень 3 боку системи гемостазу або розвитку вазопатій. Також, у хворих можуть виникати періоди тимчасомвого болю під час стійкого знеболення. Часто біль може бути зумовлений такими діагностичними маніпуляціями як аспірація кісткового мозку, трепанобіопсія, люмбальна пункція, що обумовлено травмою тканин під час медичних маніпуляцій $[6,7]$. Побічні ефекти системної хіміотерапії 
(наприклад, периферична невропатія, мукозити, біль у м’язах, біль у суглобах) також сприяють посиленню ноцицепції.

Було встановлено, що у хворих які перенесли трансплантацію кісткового мозку й імуносупресивну терапію, біль у ротовій порожнини і мукозити виникали у 75 \% випадків. Профілактика мукозитів залишається недостатньо вивченою проблемою у хворих 3 онкологічною патологією після проведення хіміотерапії.

Одним із першочергових завдань лікування больового синдрому при будь-якій патології, в тому числі при онкогематологічній, є максимально можливе зменшення впливу на органи та тканини хворого фактора альтерації, у тому числі й інфекційного походження. Наприклад, застосування антивірусної, антибактеріальної, антигрибкової терапії, санація ротової порожнини, дотримання дієти, застосовування антисептиків, аплікації локальних анестетиків, кріотерапія та системна аналгезія набувають суттєвого значення в лікуванні мукозитів після проведення інтенсивної хіміотерапії, як одного із патогеничних чинників больового синдрому [8, $9,10]$.

У пацієнтів з онкогематологічною патологією при проведенні інтенсивної цитостатичної терапії досить часто виявляють больові ускладнення постгерпетичного походження. Причиною розвитку герпетичного ураження $є$ герпетична інфекція, яка розвивається на тлі імуносупресії. В результаті виникає посгерпетична нейропатія, що супроводжується значним больовим синдромом [11]. Пацієнтам з вірусною невропатією та невралгією необхідно призначати відповідну противірусну терапію. Це дає змогу запобігти проявам нейропатичного болю. Знеболення при цьому ускладненні можна проводити за допомогою комбінації габапентіну з трамадолом [12]. Необхідно зважати на те, що дози та конкретні знеболюючі препарати має визначати лікуючий лікар у відповідності до клінічної ситуації.

При проведенні лікувально-діагностичних маніпуляцій для ефективного зменшення болю важливим $\epsilon$ адекватний вибір відповідних препаратів з урахуванням їх початкової дози та особливостей фармакокінетики 3 метою підтримання достатньої концентрації в плазмі крові. Це дозволяє проводити ефективне блокування прогресування больового синдрому. Призначення препаратів необхідно здійснювати у відповідності до існуючих рекомендацій, але в кожному окремому випадку лікар має враховувати індивідуальні характеристики пацієнта. Необхідно зважати на той факт, що комплексне застосування різних знеболюючих препаратів може мати перевагу перед монотерапією, наприклад опіатами, за рахунок зменшення кількості побічних ефектів. 
У хворих на мієломну хворобу біль в кістках є головною клінічною маніфестацією. Він супроводжується зростанням рівня лактатдегідрогенази та еритробластів в периферичній крові i може свідчити про наявність кісткового некрозу. У цієї категорії пацієнтів та інших онкогематологічних хворих при виникненні болю в кістках, який зумовлений остеолітичними процесами, рекомендують призначати біфосфонати (парамідронат, цолендронат). Крім того, золендронова кислота в комбінації 3 радіоактивним компонентами, такими як самаріум 153 етилен діамін, на сьогодні є перспективним методом аналгезії. Для хворих, які не відповідають на ці терапевтичні засоби, лікуванням вибору є проведення паліативної радіотерапії [13-18].

Препарати для аналгезії можуть бути складовою частиною антинеопластичної хіміотерапії та паліативної радіотерапії. При призначенні препаратів для аналгезії онкогематологічних хворих треба брати до уваги не лише описані в інструкції побічні ефекти, але й можливий індивідуальний вплив лікарських засобів на рівень нейтрофілів, тромбоцитів, показники функціонального стану печінки та нирок тощо. Це дозволяє запобігти розвитку ускладнень та підвищити ефективність лікування [19].

Нестероїдні протизапальні препарати слід призначати з обережністю у хворих 3 порушеннями ниркового кровообігу та у пацієнтів із ризиком кровотечі внаслідок тромбоцитопенії, дисфункції тромбоцитів, коагулятційних порушень, що можуть бути наслідком лікування онкогематологічної патології, або ж самостійним патологічним станом, що супроводжує перебіг основного захворювання.

Залежно від типу, інтенсивності та походження болю застосовують різні варіації методів знеболення. Опіоїди займають головне місце в знеболенні онкогематологічних хворих. Їх підрозділяють відповідно дії на рецептори - агоністи, часткові агоністи, агоністи-антагоністи і антагоністти. В залежності від інтенсивності болю можуть застосовуватися як слабко- та сильнодіючі опіоїди. Хворим зі слабким болем, як правило, наркотичні анальгетики не призначають. За умови відсутності протипоказань лікарськими засобами вибору є нестероїдні протизапальні препарати (НПЗП) (парацетамол, целекоксиби). При помірному больовому синдромі доведена ефетивність кодеїну, оксикодону, бупренорфіну i трамадолу. Сильні опіоїди (морфін, метадон, фентаніл) рекомендується застосовувати при тривалому помірному або сильному больовому синдромі [20]. Метадон більш показаний у хворих з нейропатичним болем та у випадку небажаних проявів при застосуванні інших опіоїдів [21]. Лікарські форми опіоїдних препаратів, що призначені для трансдермального введення 
(бупренорфін, фентаніл), мають менше побічних дій, зокрема зменшується ризик виникнення закрепу $[22,23]$. Трансдермальне призначення фентанілу може бути ефективним альтернативним шляхом знеболення у хворих із цитотоксичним стоматитом після проведення хіміотерапії. Альтернативою трансдермальним методам введення $\epsilon$ анальгезуючий електрофорез у хворих із злоякісними пухлинами в кістках.

Залишається недостатньо вивченим лікування хворих 3 мієлоїдною полінейропатією у випадках, коли воно спрямоване не тільки на корекцію функціональних порушень, але й на купірування болю завдяки застосуванню габапентіну з трамадолом чи трансдермальному введенні фентанілу $[24,25]$.

Опіоїди $є$ основою лікування помірного і важкого вісцерального ноцицептивного болю у пацієнтів з нейтропенічним колітом після проведення високодозової хіміотерапії, а ноцицептивний соматичний (шкіра, слизові, м'язи та кістки) біль корегується, переважно, нестероїдними протизапальними засобами або комплексом нестероїдних протизапальних та опіоїдних препаратів.

Відповідно до даних В. М. Бобирьова та співавт. [26] зменшення знеболюючої дії опіатів відбувається в наступному порядку: суфетаніл $\rightarrow$ фентаніл $\rightarrow$ бупренорфін (норфін) $\rightarrow$ алфентаніл $\rightarrow$ оксиморфон $\rightarrow$ леворфанол $\rightarrow$ буторфанол (морадол) $\rightarrow$ гідроморфон $\rightarrow$ метадон $\rightarrow$ морфін $\rightarrow$ омнопон $\rightarrow$ налбуфін $\rightarrow$ піритридамід (дипідолор) $\rightarrow$ промедол $\rightarrow$ естоцин $\rightarrow$ пентазоцин $\rightarrow$ кодеїн $\rightarrow$ тилідин $\rightarrow$ трамадол $\rightarrow$ пропоксифен.

Необхідно зауважити, що аналгезуюча дія морфіну триваліша у хворих похилого віку, при порушенні функції нирок та печінки.

Загальну дозу опіоїдів, що буде застосована впродовж 24 годин, розраховують у відповідності від методу введення (перорально, трансдермально та ін.). Необхідно брати до уваги також гідратацію хворого та взаємодію лікарських препаратів (синергізм, антагонізм). За наявності побічних ефектів призначають менші дози опіоїдів, враховуючи при цьому метод їх введення та тривалість дії впродовж доби. При призначенні препаратів у онкологічних хворих враховують стан хворого, порушення його свідомості (чи може він ковтати, чи має місце блювота, кишкова непрохідність, тяжка дисфагія).

Внутрішньовенне введення аналгетичних препаратів застосовують у пацієнтів для швидкого заспокоєння болю, або за наявності не контрольованого больового синдрому. Після зменшення інтенсивності болю опіоїди можливо застосовувати в еквівалентних дозах шляхом орального 
чи трансдермального введення. У хворих, яким контролюють аналгезію, можлива постійна інфузія препарату, але, за необхідності, передбачене bolus введення препаратів. Введення bolus-доз залежить від прохання онкологічного хворого, що в більшості випадків може бути обгрунтовано інтенсивністю проявів больового синдрому.

У хворих з тромбоцитопенією, тромбоцитопатією та за наявності коагулопатії, а також із ризиком виникнення ниркової недостатності, в залежності від інтенсивності болю, можна використовувати парацетамол, целекоксиб і трамадол [27], так як зазначені препарати у терапевтичних дозах мінімально впливають на коагуляційний потенціал крові.

У пацієнтів з онкогематологічною патологією в період ремісії, при продовженні опіоїдної терапії, можуть розвиватися ниркові порушення за рахунок змін ниркової екскреції та змін в імунній системі [28].

На сьогодні проведено ідентифікацію морфінових рецепторів гемопоетичних клітин, визначено їхній зв'язок між походженням болю, опіоїдами і імунною системою. Імуноцити й нейтрофіли беруть участь в інгібуванні болю, продукуванні та локальній секреції до вогнищевих тканин пептидних ендогенних опіоїдів таких як ендорфіни, енкефаліни і дінорфіни. Вивчається імуносупресивна дія опіоїдних препаратів, котра не пов'язана з їхніми антиноцептивними якостями. Отримані результати дослідження свідчать, що морфін має суттєву імуносупресивну дію, кодеїн виявляє слабкий аналгезуючий та імуносупресивний ефекти. В той же час, метадон і трамадол менше пригнічують імунну систему при короткостроковому і тривалому застосуванні [29, 30, 31].

Інколи больовий синдром неможливо усунути, що обумовлено недостатньою чутливістю рецепторів або набутою ними резистентністю до опіоїдів. В інших випадках це зумовлено прогресуванням захворювання та появою небажаних ефектів, підвищенням чутливості до больових подразників, появою нейропатичного болю, продукуванням опіоїдних метаболітів. Недостатня чутливість до опіоїдів також може бути наслідком дії оксиду азоту, який продукують злоякісні клітини [32, 33, 34].

Створення програми комбінованого застосування аналгетичних медикаментозних засобів дає можливість зменшити небажані побічні ефекти завдяки зниженню дозування препаратів i різниці у характеристиці застосованих ліків. Слід зазначити, що НПЗП можуть бути терапевтичним компонентом на всіх етапах програмованої аналгезії. Причому найбільший інтерес викликають комбінації опіатів та НПЗП або НПЗП і місцевих анестетиків. Комбіноване застосування опіатів та НПЗП, що діють синергічно, є ефективнішим ніж призначення препаратів кожної групи 
окремо. Це дає можливість уникнути звикання, використовувати меншу дозу кожного препарату, підвищувати антиноцицептивний потенціал i, таким чином, зменшити частоту побічних ефектів кожної групи препаратів [35, 36, 37].

Незважаючи на численну інформацію про етіологію та патогенез больового синдрому, розкриття нових патогенетичних аспектів болю у хворих з онкогематологічною патологією може сприяти удосконаленню схем призначення знеболюючих засобів.

Впровадження відповідного алгоритму комплексного лікування хворих 3 больовим синдромом при онкогематологічній патології може позитивно моделювати перебіг захворювання, сприяти покращенню якості життя цих пацієнтів, зменшити прямі та непрямі витрати на лікування.

\section{Література}

1. Зупанець IB, Рубан ОА, Свтушенко ОМ, Колісник ТЄ. Дослідження асортименту аналгетичних засобів для терапії хронічного болю на фармацевтичному ринку України. Фармацевтичний журнал. 2020; 75(3): 16-28.

DOI: $10.32352 / 0367-3057.3 .20 .02$

2. The International Association for the Study of Pain [Електронний ресурс]. - Режим доступу: https://www.iasppain.org/

3. International Association for the Study of Pain Taxonomy: Nociceptive Pain. IASP. Режим доступу: https://www.iasp-pain.org/Education/ Content.aspx?ItemNumbe $\mathrm{r}=1698 \#$ Nociceptivepain. Accessed on May 16, 2018.

4. International Association for the Study of Pain Taxonomy: Neuropathic Pain. IASP. Режим доступу: https://www.iasp-pain.org/Education/ Content. aspx? Item Number=1698\# Neuropathicpain. Accessed on May 16,2018

\section{Refereces}

1. Zupanets`IV, Ruban OA, Yevtushenko OM, Kolisnyk TYE. Doslidzhennya asotsiatsiyi analhetychnykh zasobiv dlya terapiyi khronichnoho bolyu na farmatsevtychnomu rynku Ukrayiny. Farmatsevtychnyy zhurnal. 2020; 75 (3): 16-28.

DOI: $10.32352 / 0367-3057.3 .20 .02$

2. The International Association for the Study of Pain [Electronic resource]. - Access mode: https://www.iasppain.org/

3. International Association for the Study of Pain Taxonomy: Nociceptive Pain. IASP. Access mode: https://www.iasp-pain.org/Education/ Content.aspx? ItemNumber $=1698 \#$ Nociceptivepain. Accessed on May $16,2018$.

4. International Association for the Study of Pain Taxonomy: Neuropathic Pain. IASP. Access mode:

https://www.iasp-pain.org/Education/ Content. aspx? Item Number $=1698 \#$ Neuropathicpain. Accessed on May 16,2018 
5. Ван-Роенн ДХ, Пєйс ДА, Преодер МИ. Диагностика и лечение боли. Пер. $з$ англ. Москва. Видавництво «Біном»; 2012. 496 c.

6. Niscola P, Cartoni C, Romani C, et al Epidemiology, features and outcome of pain in patients with advanced hematological malignancies followed in a home care program: an Italian survey. Annals of hematology. 2007; 86(9): 671-6.

7. Caraceni A.; Shkodra M. Cancer Pain Assessment and Classification. Cancers. 2019; 11: 510.

8. Fisher BT, Zaoutis T, Dvorak CC, et al. Effect of Caspofungin vs Fluconazole Prophylaxis on Invasive Fungal Disease Among Children and Young Adults With Acute Myeloid Leukemia: A Randomized Clinical Trial. JAMA. 2019; 322(17): 167381.

doi: 10.1001/jama.2019.15702

9. Hong J, Park HK, Park S, et al. Strong association between herpes simplex virus-1 and chemotherapyinduced oral mucositis in patients with hematologic malignancies. Ko. rean J Intern Med. 2020; 35(5): 1188-98. doi: 10.3904/kjim.2018.469

10.Sakshi S. Effects of chemotherapy on oral mucosa. Journal of Academy of Dental Education. 2020; 6(1\&2): 11-5.

11. Goenaga VY, Cabanillas F, Concepción JR, Díaz MOL Incidence and risk factors for developing herpes zoster among a cohort of patients diagnosed with lymphoma at a community cancer center. Clin Lymphoma Myeloma Leuk. 2019; 19: 153-8. https://doi.org/10.1016/ j.clml.2018.12.001
5. von Roenn JH, Paice JA, Preodor ME, Current Diagnosis \& Treatment of Pain. McGraw Hill; 2006. 349 p.

6. Niscola P, Cartoni C, Romani C et al Epidemiology, features and outcome of pain in patients with advanced hematological malignancies followed in a home care program: an Italian survey. Annals of hematology. 2007; 86(9): 671-6.

7. Caraceni A.; Shkodra M. Cancer Pain Assessment and Classification. Cancers. 2019; 11: 510.

8. Fisher BT, Zaoutis T, Dvorak CC, et al. Effect of Caspofungin vs Fluconazole Prophylaxis on Invasive Fungal Disease Among Children and Young Adults With Acute Myeloid Leukemia: A Randomized Clinical Trial. JAMA. 2019; 322 (17): 1673-81. doi: 10.1001/jama.2019.15702,

9. Hong J, Park HK, Park S, et al. Strong association between herpes simplex virus-1 and chemotherapyinduced oral mucositis in patients with hematologic malignancies. Korean J Intern Med. 2020; 35(5): 1188-98. doi: 10.3904/kjim.2018.469

10.Sakshi S. Effects of chemotherapy on oral mucosa. Journal of Academy of Dental Education. 2020; 6(1\&2): 11-5.

11. Goenaga VY, Cabanillas F, Concepción JR, Díaz MOL Incidence and risk factors for developing herpes zoster among a cohort of patients diagnosed with lymphoma at a community cancer center. Clin Lymphoma Myeloma Leuk. 2019; 19: 153-8. https://doi.org/10.1016/ j.clml.2018.12.001 
12. Дорошенко ОО. Досвід застосування габантину у пацієнтів 3 невропатичним болем при онкогематологічних захворюваннях. Галицький лікарський вісник. 2012; 19(2): 27-9.

13. Солодянникова ОI, Даниленко BВ, Саган ДЛ, Сукач ГГ Оцінка протибольової дії 153Sm-оксабіфору у хворих 3 метастатичним ураженням кісток. Радіологія в Україні: III Націон. конгрес 3 міжнар. участю : (тези та короткі повідом.). 25-27 березня 2015. Київ. Радіол. вісник. 2015; 1-2 (54-55): 117.

14. Грушка ГВ, Луховицька НI., Ткаченко ГІ та ін. Радіонуклідна терапія метастатичного ураження кісткової системи в поєднанні 3 хірургічним лікуванням, хіміотерапією та із застосуванням бісфосфонатів. Український радіологічний журнал. 2017; 25 (3): 23841.

15. Novita G, Frasson A, Millen E, Zerwes F, Cavalcante F. Breast Diseases. Springer. 2019. 604 c. https://doi.org/10.1007/978-3-03013636-9 68

16. Raje N, Terpos E, Willenbacher W et al. Denosumab versus zoledronic acid in bone disease treatment of newly diagnosed multiple myeloma: an international, double-blind, double-dummy, randomised, controlled, phase 3 study. The Lancet Oncology. 2018; 19 (3): 370-81.

https://doi.org/10.1016/S14702045 (18)30072-X

17. Rajkumar SV. Multiple myeloma: Every year a new standard? Hematological Oncology. 2019; 37(S1): $62-$ 5. https://doi.org/10.1002/hon.2586
12. Doroshenko OO. Dosvid zastosuvannya habantyny $\mathrm{u}$ patsiyentiv $\mathrm{z}$ nevropatychnymy bolem pry onkohematolohichnykh zakhvoryuvannyakh. Halyts`kyy likars`kyy visnyk. 2012; 19 (2): 27-9.

13. Solodyannikova O.I., Danylenko V.V., Sahan DL, Sukach H.H. Radiolohiya v Ukrayini: III Natsion. Konhres $\mathrm{z}$ mizhnar. uchastyu: (tsi ta korotki povidomlennya.). 25-27 bereznya 2015. Kyiv. Radiol. visnyk. 2015; 1-2 (54-55): 117.

14. Hrushka HV, Lukhovyts'ka NI., Tkachenko HI ta in. Radionuklidna terapiya metastatychnoho urazhennya kistkovoyi systemy $\mathrm{v}$ poyednanni z khirurhichnymy metodamy likuvannya, khimioterapiyeyu ta iz zastosuvannyam bisfosfonativ. Ukrayins`kyy radiolohichnyy zhurnal. 2017; 25 (3): 238-41.

15. Novita G, Frasson A, Millen E, Zerwes F, Cavalcante F. Breast Diseases. Springer. 2019. 604 p. https://doi.org/10.1007/978-3-03013636-9 68

16. Raje N, Terpos E, Willenbacher W et al. Denosumab versus zoledronic acid in bone disease treatment of newly diagnosed multiple myeloma: an international, double-blind, double-dummy, randomised, controlled, phase 3 study. The Lancet Oncology. 2018, 19 (3), 370-381.

https://doi.org/10.1016/S14702045 (18)30072-X

17. Rajkumar SV. Multiple myeloma: Every year a new standard? Hematological Oncology. 2019; 37(S1): $62-$ 5. https://doi.org/10.1002/hon.2586 
18. Rasch S; Lund T; Asmussen JT et al. Multiple Myeloma Associated Bone Disease. Cancers. 2020; 12: 2113. https://doi.org/10.3390/cancers 1208 2113

19. Левченко ОК, Берсенева ЕА. Особенности диагностики боли у пациентов с заболеваниями системы крови. Вестник современной клинической медицины. 2018; 11(3): 65-76 DOI: 10.20969/VSKM

20. Левченко ОК, Берсенева ЕА, Савченко ВГ. Организационные и медицинские аспекты назначения опиоидов у пациентов с заболеваниями системы крови. Российский журнал боли. 2018; 3: 60-70.

21. Mcnicol ED; Ferguson MC; Schumann R. Methadone for neuropathic pain in adults. Cochrane Database of Systematic Reviews. 2017. 5.

22.Pergolizzi Jr, Joseph V., et al. Transdermal buprenorphine for acute pain in the clinical setting: a narrative review. Journal of Pain Research. 2021; 14: 871.

23. Golčić M, Dobrila-Dintinjana R, Golčić G, Gović-Golčić L. Differences between transdermal fentanyl and buprenorphine in the elderly hospice patients. Pain research and treatment. 2018. https://doi.org/ $10.1155 / 2018 / 8610538$

24. El-Jawahri A., LeBlanc TW, \& Temel JS. Integrated Palliative and Oncology Care for Patients With Acute Myeloid Leukemia-Moving From Evidence to Practice-Reply. JAMA oncology. 2021; 7(6): 943-4.

25. Zajączkowska, R., Mika, J., Leppert, W., Kocot-Kępska, M., MalecMilewska, M., \& Wordliczek, J. Mirogabalin-A Novel Selective Ligand for the $\alpha 2 \delta$ Calcium Channel
18. Rasch S; Lund T; Asmussen JT et al. Multiple Myeloma Associated Bone Disease. Cancers. 2020; 12: 2113. https://doi.org/10.3390/cancers 1208 2113

19. Levchenko OK, Berseneva YEA. Osobennosti diagnostiki u patsiyentov s zabolevaniyami sistemy krovi. Vestnik sovremennoy klinicheskoy meditsiny. 2018; 11 (3): 65-76

DOI: 10.20969 / VSKM

20. Levchenko OK, Berseneva YEA, Savchenko VG. Organizatsionnyye i meditsinskiye aspekty naznacheniya opioidov u patsiyentov s zabolevaniyami sistemy krovi. Rossiyskiy zhurnal boli. 2018; 3: 60-70.

21. Mcnicol ED; Ferguson MC; Schumann R. Methadone for neuropathic pain in adults. Cochrane Database of Systematic Reviews. 2017. 5.

22. Pergolizzi Jr, Joseph V., et al. Transdermal buprenorphine for acute pain in the clinical setting: a narrative review. Journal of Pain Research. 2021; 14: 871.

23. Golčić M, Dobrila-Dintinjana R, Golčić G, Gović-Golčić L. Differences between transdermal fentanyl and buprenorphine in the elderly hospice patients. Pain research and treatment.2018. https://doi.org/ $10.1155 / 2018 / 8610538$

24. El-Jawahri A., LeBlanc TW, \& Temel JS. Integrated Palliative and Oncology Care for Patients With Acute Myeloid Leukemia-Moving From Evidence to Practice-Reply. JAMA oncology. 2021; 7(6): 943-4.

25. Zajączkowska, R., Mika, J., Leppert, W., Kocot-Kępska, M., MalecMilewska, M., \& Wordliczek, J. Mirogabalin-A Novel Selective Ligand for the $\alpha 2 \delta$ Calcium Channel 
Subunit. Pharmaceuticals. 2021; 14(2): 112 .

26. Бобирьов ВМ, Петрова ТА, Островська ГЮ. Внутрішні хвороби. Фармакотерапія больового синдрому. 2003. $213 \mathrm{c}$.

27. Каратеев AE Анальгетическая терапия и проблема коморбидности. Современная ревматология. 2019; 3: 116-25.

28. Karmali RN, Bush C, Raman SR, Campbell CI, Skinner AC, Roberts AW. Long-term opioid therapy definitions and predictors: A systematic review. Pharmacoepidemiol Drug Saf. 2020; 29: 252-69

29. Rogers TJ. Bidirectional Regulation of Opioid and Chemokine Function. Frontiers in Immunology. 2020; 11: 94. DOI: 10.3389/ fimmu. 2020.00094 PMID: 32076421; PMCID: PMC7006827

30. Rogers TJ. Kappa Opioid Receptor Expression and Function in Cells of the Immune System. Handbook of Experimental Pharmacology. 2021. Feb. DOI: 10.1007/164_2021_441. PMID: 33580386

31. Brejchova J; Holan V; Svoboda P. Expression of Opioid Receptors in Cells of the Immune System. Int. J. Mol. Sci. 2021; 22: 315. https://doi.org/10.3390/ijms22010315

32. Morrone LA, Scuteri D, Rombola L, et al. Opioids Resistance in Chronic Pain Management. Current neuropharmacology. 2017; 15: 444-56.

33. Переверзев ДИ, Погорелов ВВ, Симонова НВ, Доровских ВА Опыт применения длительной интратекальной опиоидной терапии в лечении фармакорезистентного нейропатического болевого синдрома. Бюл. физ. и пат. дых. 2018; 69: 93-6.
Subunit. Pharmaceuticals. 2021; 14(2): 112.

26. Bobyr'ov VM, Petrova TA, Ostrovs'ka HYU. Vnutrishni khvoroby. Farmakoterapiya bol'ovoho syndromu. 2003. $213 \mathrm{p}$.

27. Karateyev AYe Anal'geticheskaya terapiya i problema komorbidnostiyu. Sovremennaya revmatologiya. 2019; 3: 116-25

28. Karmali RN, Bush C, Raman SR, Campbell CI, Skinner AC, Roberts AW. Long-term opioid therapy definitions and predictors: A systematic review. Pharmacoepidemiol Drug Saf. 2020; 29: 252-69

29. Rogers TJ. Bidirectional Regulation of Opioid and Chemokine Function. Frontiers in Immunology. 2020; 11: 94. DOI: 10.3389/ fimmu. 2020.00094 PMID: 32076421; PMCID: PMC7006827

30. Rogers TJ. Kappa Opioid Receptor Expression and Function in Cells of the Immune System. Handbook of Experimental Pharmacology. 2021. Feb. DOI: $10.1007 / 164 \_2021 \_441$. PMID: 33580386

31. Brejchova J; Holan V; Svoboda P. Expression of Opioid Receptors in Cells of the Immune System. Int. J. Mol. Sci. 2021; 22: 315. https://doi.org/10.3390/ijms22010315

32. Morrone LA, Scuteri D, Rombola L, et al. Opioids Resistance in Chronic Pain Management. Current neuropharmacology. 2017; 15: 444-56.

33.Pereverzev DI, Pogorelov VV, Simonova NV, Dorovskikh VA Opyt primeneniya dlitel'noy intratekal'noy opioidnoy terapii v lechenii farmakorezistentnogo neyropaticheskogo bolevogo sindroma. Byul. fiz. i pat. dykh. 2018; 69: 93-6. 
34. Колесников ЮА Центральные и периферические механизмы мюопиоидной анальгезии и толерантности. Вестник анестезиологии и реаниматологии. 2020; 1: 9-20.

35. Пчелинцев МВ Болевой синдром в онкологии. Возможности применения декскетопрофена. МC. 2020; 9: 146-54.

36. Varrassi G, Yeam CT, Rekatsina $\mathrm{M}$, et al. The Expanding Role of the COX Inhibitor/Opioid Receptor Agonist Combination in the Management of Pain. Drugs. 2020; 80: 1443-53

37. Liu Z, Xu Y, Liu Zl, et al. Combined application of diclofenac and celecoxib with an opioid yields superior efficacy in metastatic bone cancer pain: a randomized controlled trial. Int J Clin Oncol. 2017; 22: 980-5

Стаття надійшла 16.08.2021

Контакти: siemleonv@gmail.com
34. Kolesnikov YUA Tsentral'nyye i perifericheskiye mekhanizmy myuopioidnoy anal'gezii i tolerantnosti. Vestnik anesteziologii i reanimatologii. 2020; 1: 9-20.

35. Pchelintsev MV Bolevoy sindrom v onkologii. Vozmozhnosti primeneniya deksketoprofena. MS. 2020; 9: 146-54.

36. Varrassi G, Yeam CT, Rekatsina $\mathrm{M}$, et al. The Expanding Role of the COX Inhibitor/Opioid Receptor Agonist Combination in the Management of Pain. Drugs. 2020; 80: 1443-53

37. Liu Z, Xu Y, Liu Zl, et al. Combined application of diclofenac and celecoxib with an opioid yields superior efficacy in metastatic bone cancer pain: a randomized controlled trial. Int J Clin Oncol. 2017; 22: 980-5 